\title{
ANALYSIS OF LUBRICANT ACTION OF BIODIESEL USING RESPONSE SURFACE METHODOLOGY*
}

Valdicleide Silva Mello' Salete Martins Alves ${ }^{2}$

\begin{abstract}
Nowadays the biodiesel use is obligate in Brazil, in order to reduce the emissions of fuel burn. However, it is important to analyze which percentage of biodiesel is necessary to keep or improve the lubricant action of fuel for diesel engine, as well which kind of biodiesel give better performance. Therefore, this work aims to analyze the parameters that keep the lubricant action of biofuels, by using the Box-Behnken design type to optimize them. In this design was evaluated the input parameters: the type of the biodiesel (soybean, sunflower and palm), the concentration (5\%, $20 \%$ and $100 \%)$ and the temperature of contact $\left(25^{\circ} \mathrm{C}, 40^{\circ} \mathrm{C}\right.$ and $\left.60^{\circ} \mathrm{C}\right)$. The analyzed output parameters were the percentage of film formation, coefficient of friction, wear scar diameter (WSD) of ball, these output parameters were obtained by HFRR tribometer and they were analyzed applying response surface methodology. With this methodology was possible to determine the simultaneous influence and the interactions between two or more independent variables investigated. The response surfaces generated for the coefficients of friction, WSD, film formation showed a higher lubricant action for higher levels of concentration of biodiesel. An increase in lubricant action was found to high and intermediate temperature.
\end{abstract}

Keywords: Biodiesel; Lubricity, Response surface methodology.

1 Master in Mechanical Engineering, Member of the group Tribology and Structural Integrity- GET, PPGEM, Federal University of Rio Grande do Norte (UFRN), Natal, Rio Grande do Norte, RN, Brazil.

2 Doctor in Mechanical Engineering, Sciences and Technology School, Federal University of Rio Grande do Norte (UFRN), Natal, Rio Grande do Norte, RN, Brazil.

* Technical contribution to the $2^{\text {nd }}$ International Brazilian Conference on Tribology - TriboBR 2014, November $3^{\text {rd }}$ to $5^{\text {th }}$, 2014, Foz do Iguaçu, PR, Brazil. 


\section{INTRODUCTION}

The great attention given to biodiesel in recent years is due mainly to its renewable character and its sustainable use that minimizes environment damages, as well emissions reduction compared to diesel from petroleum. Also, it has biodegradable and nontoxic character [1].

In the Brazilian energy matrix, the biodiesel use is regulated in $5 \%$ biodiesel blended with diesel. However, in this year the biodiesel proportion will increase to $7 \%$ [2].

Associated to growth biodiesel demand, there is a greater concern in controlling the fuel quality, because of its natural process of degradation, corrosion or tampering, and consequently of their blends with diesel.

Some studies have shown that biodiesel blends can promote falling power. However, this fact is not directly associated to the increase of biodiesel in the mixture. According to Corrêa [3] the power developed with some of the intermediate mixtures was equal of diesel or the obtained with B100. The result of B20 was slightly higher than B100 biodiesel from sunflower oil and the changes observed in the analysis of lubricating oil were considered acceptable, once it would not compromise the performance of the engine.

The diesel engines require that the fuel has lubricating properties, avoiding direct contact between pieces in movement. Biodiesel presents superior lubricity than diesel, becoming an alternative to replace the diesel.

Furthermore, the introduction of the low sulfur diesel has generated some serious problems in fuel properties. With desulfurization process, the lubricity decreases due to minimization of sulfur by the removal of polar compounds (phenols and polyaromatic) and oxygen [5-7].

Thus, the diesel engine with low sulfur content requires suitable additives to improve the lubricating properties. In their studies, Mello et al. [4] evaluated the effect of the low sulfur diesel (LSD) and high sulfur diesel (HSD) on diesel lubricity. Also, they studied the Biodiesel addition in diesel. A lower lubricity was detected for diesel with low sulfur diesel in relation to the high sulfur content. For blends with biodiesel from soybean and sunflower, the wear scar diameters (WSD) were lower showing higher lubricity.

Suarez et al. [8] analyzed lubricity through tribological tests in HFRR (High Frequency Reciprocating Rig), in terms of WSD and coefficient of friction. Diesel LSD or HSD and their blends as soybean biodiesel, obtained by the methods of pyrolysis and methanolysis, were evaluated. The results showed lower friction coefficients for mixtures of LSD and biodiesel (5 and 20\%) than LSD. Blends of HSD with biodiesel obtained from soybean methyl Transesterification (50 and 100\%) showed the lowest friction coefficients.

According to Wadumesthrige et al. [9] lubricity is related to organic compounds that contain a polar part, sulfurized or not. These form a boundary layer on the metal surface to protect it from wear. The nitrogen, oxygen and polyaromatic compounds, followed by sulfur compounds, even at low concentrations, act as natural precursors that confer lubricity necessary for the good diesel performance [10]. Another parameter that affects the lubricity is the temperature, sometimes positively, sometimes negatively. Wadumesthrige et al. [9] observed that the lubricity decreases with increasing temperature between 20 and $70^{\circ} \mathrm{C}$, for blends of $2 \%$ of biodiesel in LSD. However, for high temperature $\left(80\right.$ to $\left.90^{\circ} \mathrm{C}\right)$, these blends showed an increase lubricity. The positive effect on lubricity at high temperatures is due to the increased molecular motion of polar components, allowing their better distribution on the metal.

* Technical contribution to the $2^{\text {nd }}$ International Brazilian Conference on Tribology - TriboBR 2014, November $3^{\text {rd }}$ to $5^{\text {th }}$, 2014, Foz do Iguaçu, PR, Brazil. 
Thus, the chemical adsorption of polar compounds to the metal surface is higher at higher temperatures.

In this work, the fuel lubricity was evaluated through a statistical tool that allows to analyze the variables and their combinations to obtain an response optimized. The response surface methodology or RSM is a collection of statistical and mathematical methods that are useful for modeling and analysis of engineering problems. In this technique the main goal is to optimize the response surface that is influenced by several process parameters and to quantify the relationship between the controllable input parameters and response surface obtained by the combination of input data [11].

The experimental design of Box-Behnken type is applied in experiments response surface, where the use of factors with 3 levels (low, medium, high) is needed, and in this case the Box-Behnken experimental are a good alternative for the design of central compound. Moreover, there is enough information to perform a test of lack fit, and provide symmetry of the arrangement of points in the cube.

\section{MATERIALS AND METHODS}

The experimental design of the Box-Behnken, with triplicate in the center point, was used for tests analyzing wear and lubricating ability. This design is of type $3^{3}$, varying in three levels (top, bottom and center point), which are the percentage of biodiesel (B5, B20 and B100), type of biodiesel (Soybean, Sunflower and Palm) and temperature $\left(25,40\right.$ and $\left.60^{\circ} \mathrm{C}\right)$.

The results were analyzed by response surface method, which is obtained from the combination of levels and factors selected for testing. The software used was the Statistic 7.0. Levels and factors used as test parameters are showed in Table 1, with their real and coded values.

Table 1. Provision levels and actual and coded factors

\begin{tabular}{ccccc}
\hline \multirow{2}{*}{ Variable } & \multirow{2}{*}{ Symbol } & \multicolumn{3}{c}{ Coded levels } \\
\cline { 3 - 5 } & & Low & Central & High \\
\cline { 2 - 5 } & & -1 & 0 & 1 \\
\hline Biodiesel & $\mathrm{x} 1$ & Soybean & Sunflower & Palm \\
\hline Concentration $(\%)$ & $\mathrm{x} 2$ & $\mathrm{~B} 5$ & $\mathrm{~B} 20$ & $\mathrm{~B} 100$ \\
\hline Temperature $\left({ }^{\circ} \mathrm{C}\right)$ & $\mathrm{x} 3$ & 25 & 40 & 60 \\
\hline
\end{tabular}

The fuels used were synthesized by reaction ethylic transesterification of soybean and sunflower oil in molar ratios 1:6:0,001 (oil / ethanol / $\mathrm{KOH}$ catalyst) and $(1: 12: 0,025)$ for palm oil. The reagents were jointly placed into a well-stirred, round bottom glass reactor and the reaction time was 120 minutes. After the reaction, the biodiesel and glycerin phases were separated by gravity. The ethyl ester was washed with hot distilled water and then dried at $110^{\circ} \mathrm{C}$. The blends were prepared with diesel S50 (50 ppm of sulfur) in the proportions of 5, 20 and $100 \%$ of biodiesel (from soybean, sunflower and palm oil). The viscosity was determined at three temperatures $\left(25,40\right.$ and $\left.60^{\circ} \mathrm{C}\right)$ using a HAAKE MARS rheometer. The density was measured with pycnometer. Moisture [12] and the flash point [13] were measured in triplicate for all samples. The acid value was defined as the "mg" of potassium hydroxide necessary to neutralize the free acids in $1 \mathrm{~g}$ of sample.

* Technical contribution to the $2^{\text {nd }}$ International Brazilian Conference on Tribology - TriboBR 2014, November $3^{\text {rd }}$ to $5^{\text {th }}$, 2014, Foz do Iguaçu, PR, Brazil. 
Lubricity testing was done according to the HFRR method (ASTM D 6079). The HFRR operating conditions used are as follows: fluid volume $(\mathrm{mL}), 2 \pm 0.2$; applied $\operatorname{load}(\mathrm{g}), 200 \pm 1 ; \operatorname{speed}(\mathrm{Hz}), 50 \pm 1$; duration $(\mathrm{min}), 75 \pm 0.1$; stroke $(\mathrm{mm}), 1.0 \pm 0.02$. The friction coefficient, percentage of film formed and the wear scar diameter were evaluated. The independent variables were the biodiesel proportion, type of biodiesel and temperature.

Once selected the parameters and encoded the factors and levels, it is possible to produce the array of entry data within the software. With the combination of factors and levels is possible to analyze, by response surface, the conditions that provide a lowest coefficient friction and the condition for a more effective lubrication of contact Steel-Steel (AISI 52100). Tab. 2 shows the data array for lubricity testing.

Table 2. Array of experimental input data for testing the contact sphere-plane

\begin{tabular}{cccc}
\hline Test & \multicolumn{3}{c}{ Coded Variable } \\
\hline & $\mathrm{x} 1$ & $\mathrm{x} 2$ & $\mathrm{x} 3$ \\
\hline 1 & -1 & -1 & 0 \\
\hline 2 & 1 & -1 & 0 \\
\hline 3 & -1 & 1 & 0 \\
\hline 4 & 1 & 1 & 0 \\
\hline 5 & -1 & 0 & -1 \\
\hline 6 & 1 & 0 & -1 \\
\hline 7 & -1 & 0 & 1 \\
\hline 8 & 1 & 0 & 1 \\
\hline 9 & 0 & -1 & -1 \\
\hline 10 & 0 & 1 & -1 \\
\hline 11 & 0 & -1 & 1 \\
\hline 12 & 0 & 1 & 1 \\
\hline 13 & 0 & 0 & 0 \\
\hline 14 & 0 & 0 & 0 \\
\hline 15 & 0 & 0 & 0 \\
\hline
\end{tabular}

\section{RESULTS AND DISCUSSION}

Since biodiesel is produced from quite differently scaled plants of varying origins and qualities, it was necessary to establish standard of fuel quality to guarantee an engine performance without any difficulties. Table 3 shows the main properties of three different kinds of biodiesel and their blends with diesel (B5 and B20).

The acid values (Table 3) ranged from 0.36 to $1.01 \mathrm{mg} \mathrm{KOH} / \mathrm{g}$. The lowest acid value was the soybean biodiesel. The highest acid value belonged to the palm biodiesel, following the trend observed in the pure oil. However, these values were a little superior to the limits suggested by the ANP $(0.8 \mathrm{mg} \mathrm{KOH} / \mathrm{g})$. The ASTM D664 and EN 140104 standards approved a maximum acid value for a biodiesel of $0.50 \mathrm{mg}$ $\mathrm{KOH} / \mathrm{g}$. An explanation to understand the slightly elevated acidity of Palm biodiesel can be the method of production of oil, that not passed to purification process, only degumming, differently of soybean and sunflower oils that were purchased commercially and they passed through the purification process. Regarding the blends

* Technical contribution to the $2^{\text {nd }}$ International Brazilian Conference on Tribology - TriboBR 2014, November $3^{\text {rd }}$ to $5^{\text {th }}$, 2014, Foz do Iguaçu, PR, Brazil. 
with the diesel, the acidity value is reduced due to the absence of fatty acids in the diesel that are responsible for the acidity.

The moisture content of biodiesels in its pure form had to be lower than detected for diesel. The higher moisture content was detected for the sunflower biodiesel, indicating its hygroscopic character. It was observed a gradual increase of moisture with the increase of diesel proportion in the blend due to the high moisture content of diesel.

Table 3.Properties of biofuels

\begin{tabular}{|c|c|c|c|c|c|c|c|c|}
\hline \multirow{2}{*}{\multicolumn{2}{|c|}{ Biodiesel }} & \multirow{2}{*}{$\begin{array}{l}\text { Density( } \\
\left.\mathrm{Kg} / \mathrm{m}^{3}\right)\end{array}$} & \multirow{2}{*}{$\begin{array}{l}\text { Acid value } \\
(\mathrm{mg} \mathrm{KOH} / \mathrm{g})\end{array}$} & \multirow{2}{*}{$\begin{array}{l}\text { Moisture } \\
(\%)\end{array}$} & \multirow{2}{*}{$\begin{array}{l}\text { Flash } \\
\text { point }\left({ }^{\circ} \mathrm{C}\right)\end{array}$} & \multicolumn{3}{|c|}{ Viscosity (cSt) } \\
\hline & & & & & & $25^{\circ} \mathrm{C}$ & $40^{\circ} \mathrm{C}$ & $60^{\circ} \mathrm{C}$ \\
\hline \multicolumn{2}{|c|}{ B0 (DIESEL) } & 853.8 & --- & 1.59 & 64.7 & --- & --- & --- \\
\hline \multirow[t]{3}{*}{ Palm } & $\mathrm{B} 100$ & 887.1 & 1.011 & 153 & 153 & 6.7 & 5.07 & 3.38 \\
\hline & $\mathrm{B} 20$ & 842.6 & 0.96 & 62 & 62 & 4.27 & 3.12 & 2.37 \\
\hline & B5 & 836.9 & 1.41 & 62 & 62 & 4.56 & 3.56 & 2.21 \\
\hline Sunflo & B100 & 879.7 & 0.77 & 101 & 101 & 6.93 & 5.00 & 3.64 \\
\hline \multirow[t]{2}{*}{ Wer } & B20 & 845.5 & 0.41 & 66.7 & 66.7 & 3.90 & 3.19 & 2.36 \\
\hline & B5 & 838.1 & 0.52 & 67 & 67 & 3.82 & 2.98 & 2.14 \\
\hline \multirow[t]{3}{*}{ Soy } & B100 & 855.0 & 0.37 & 130 & 130 & 6.10 & 4.85 & 3.84 \\
\hline & B20 & 843.9 & 0.76 & 64.5 & 64.5 & 2.60 & 2.13 & 1.89 \\
\hline & B5 & 837.4 & 0.36 & 64.2 & 64.2 & 3.82 & 2.98 & 1.85 \\
\hline
\end{tabular}

* standard deviation values $<0.02$.

Flash point of a fuel is the temperature at which it will ignite when exposed to a flame or a spark. Flash point varies inversely with the fuel's volatility. In comparison to diesel, the three biodiesel show high flash point above $100^{\circ} \mathrm{C}$, while the diesel has a flash point of $64.7^{\circ} \mathrm{C}$. For blends, flash point decreased because of diesel proportion. The limit of flash point ranges in ASTM D93 is $93 \circ \mathrm{C}$.

Viscosity is the most important property of any fuel as it indicates the ability of a material to flow. Therefore, viscosity affects the operation of the fuel injection equipment and spray atomization. Viscosity, in the form of kinematic viscosity, is specified in biodiesel standards with the ranges being 1.9-6.0 cSt (ASTM D6751) and 3.5-5.0 cSt (EN 14214) at $40^{\circ} \mathrm{C}$. All biodiesel synthesized in this work have kinematic viscosity according to ASTM standard. It is possible to observe a severe loss of viscosity with increasing temperature around $50 \%$ in the range of $35{ }^{\circ} \mathrm{C}$. This is due to the fact that with increasing temperature, the molecules energy kinetic increases, decreasing the distance between the molecules. Thus, the intermolecular forces become less effective and the viscosity decreases with increasing temperature. The blends showed lower viscosity than biodiesel, because the diesel viscosity is 10-15 times smaller than that of biodiesel [14] and in theses blends the diesel percentage is higher than biodiesel.

After the HFRR tests, three mathematical models were generated, relating output parameters (friction coefficient, \% film formation and WSD) with input variables (fuel, temperature and concentration). These models are presented in the equations for the coefficient of friction (Equation 1), WDS (Equation 2) and percentage of film (Equation 3), respectively:

$$
\begin{gathered}
\mathrm{Y} 1=0,0983+0,0015 \mathrm{X}_{1}-0,0010 \mathrm{X}_{1}^{2}-0,0015 \mathrm{X}_{2}+0,0003 \mathrm{X}_{2}^{2}-0,0010 \mathrm{X}_{1} \mathrm{X}_{2} \\
\mathrm{Y} 2=271,8333-40,9167 \mathrm{X}_{1}-38,1667 \mathrm{X}_{1}^{2}-1,5417 \mathrm{X}_{2}-17,1250 \mathrm{X}_{2}^{2}+12,6250 \mathrm{X}_{1} \mathrm{X}_{2} \\
\mathrm{Y} 3=92,0000+2,7500 \mathrm{X}_{1}-2,0000 \mathrm{X}_{1}^{2}-4,0000 \mathrm{X}_{2}+1,0000 \mathrm{X}_{2}^{2}+0,7500 \mathrm{X}_{1} \mathrm{X}_{2}
\end{gathered}
$$

\footnotetext{
* Technical contribution to the $2^{\text {nd }}$ International Brazilian Conference on Tribology - TriboBR 2014, November $3^{\text {rd }}$ to $5^{\text {th }}$, 2014, Foz do Iguaçu, PR, Brazil.
} 
The symbols $\mathrm{Y} 1, \mathrm{Y} 2$ and $\mathrm{Y} 3$ represent the predicted values for the coefficient of friction, wear scar diameter of and film formation, respectively.

The lubricity tests carried out for biodiesels showed that higher percentages of biodiesel provide lower friction coefficients (Figure 1). The ANOVA (Table 4) generated by the statistical model applied on analyzes show low coefficients of regression, which is related to the inadequacy of the model, since it has a considerable number of degrees of freedom.

Table 4. ANOVA generated for the Coefficient of Friction

\begin{tabular}{lcccll}
\hline Factor & \multicolumn{5}{c}{ ANOVA: COEFIFCIENT OF FRICTION } \\
& R-sqr: 0.63962 & & & \\
\cline { 2 - 6 } & SS & $\begin{array}{c}\text { Degrees of } \\
\text { freedom }\end{array}$ & MS & F & $\mathrm{p}$ \\
\hline (1)Fuel & 0.000136 & 2 & 0.000068 & 4.083400 & 0.059960 \\
(2)Concentration & 0.000021 & 2 & 0.000011 & 0.638498 & 0.553007 \\
(3)Temperature & 0.000013 & 2 & 0.000007 & 0.396678 & 0.685080 \\
Error & 0.000133 & 8 & 0.000017 & & \\
Total SS & 0.000324 & 14 & & & \\
\hline
\end{tabular}
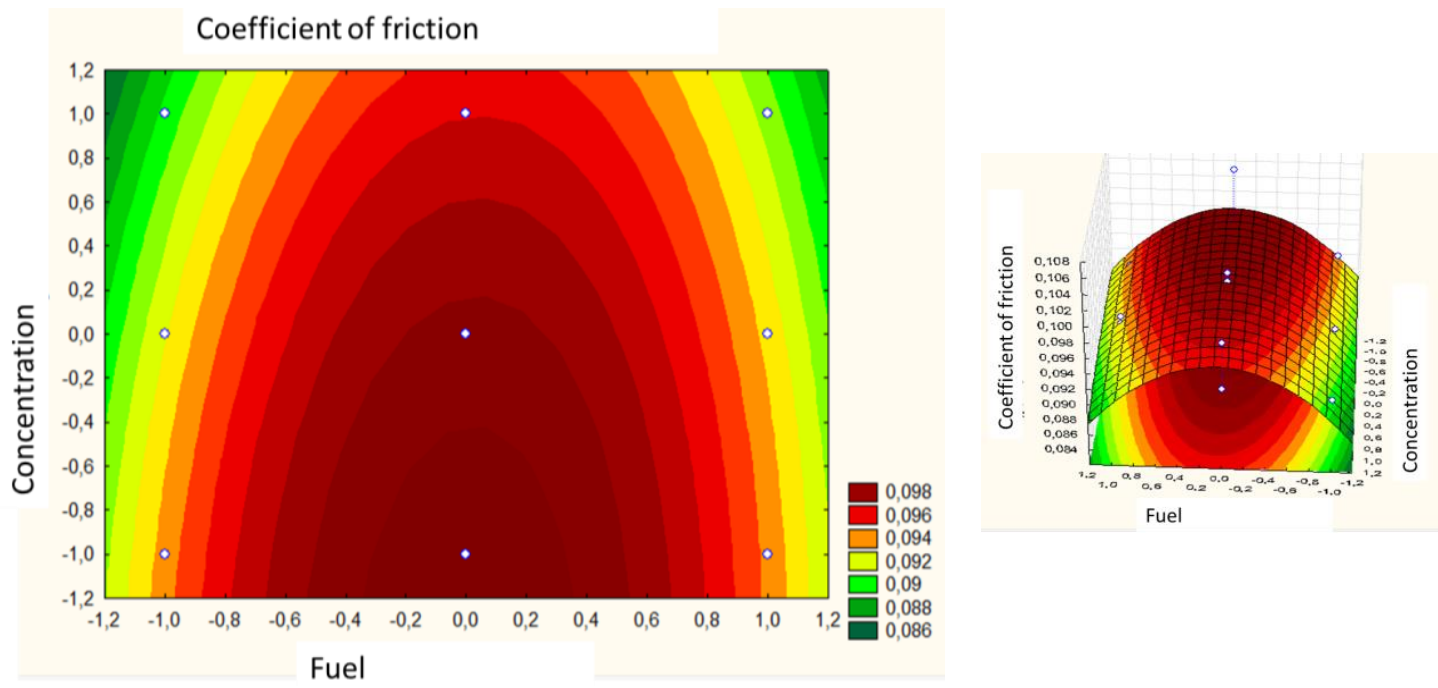

Figure 1. Response Surface and Contour generated for the coefficient of friction with respect to fuel and concentration

In the contour surface generated for the fuel is observed the lower results of coefficient of friction for higher concentration levels, i.e., for the use of biodiesels in its pure form, which was expected because the oxygen present in the ester molecule and the presence of carboxylic acids improve the lubricity [14-16]. Such behavior is observed for the three types of biodiesels at higher levels. However, statistical errors observed in the model used were higher than expected $(0.05$ for $95 \%$ level of confidence). The trend of responses corresponds to that proposed by previous studies in this area [4-6,8]. It means that the friction coefficient decreases as the concentration of biodiesel increases. In relation to fuels, higher coefficients of friction were observed for sunflower biodiesel, probably due to the moisture (Table 1) present in this fuel. According to Fazal et al [17], the high moisture absorption seems to act as a factor that potentiates the corrosiveness of biodiesel.

The temperature influence on friction coefficient is showed in Figure 2. It is possible to observe the coefficient of friction decrease at a high temperature level.

* Technical contribution to the $2^{\text {nd }}$ International Brazilian Conference on Tribology - TriboBR 2014, November $3^{\text {rd }}$ to $5^{\text {th }}$, 2014, Foz do Iguaçu, PR, Brazil. 

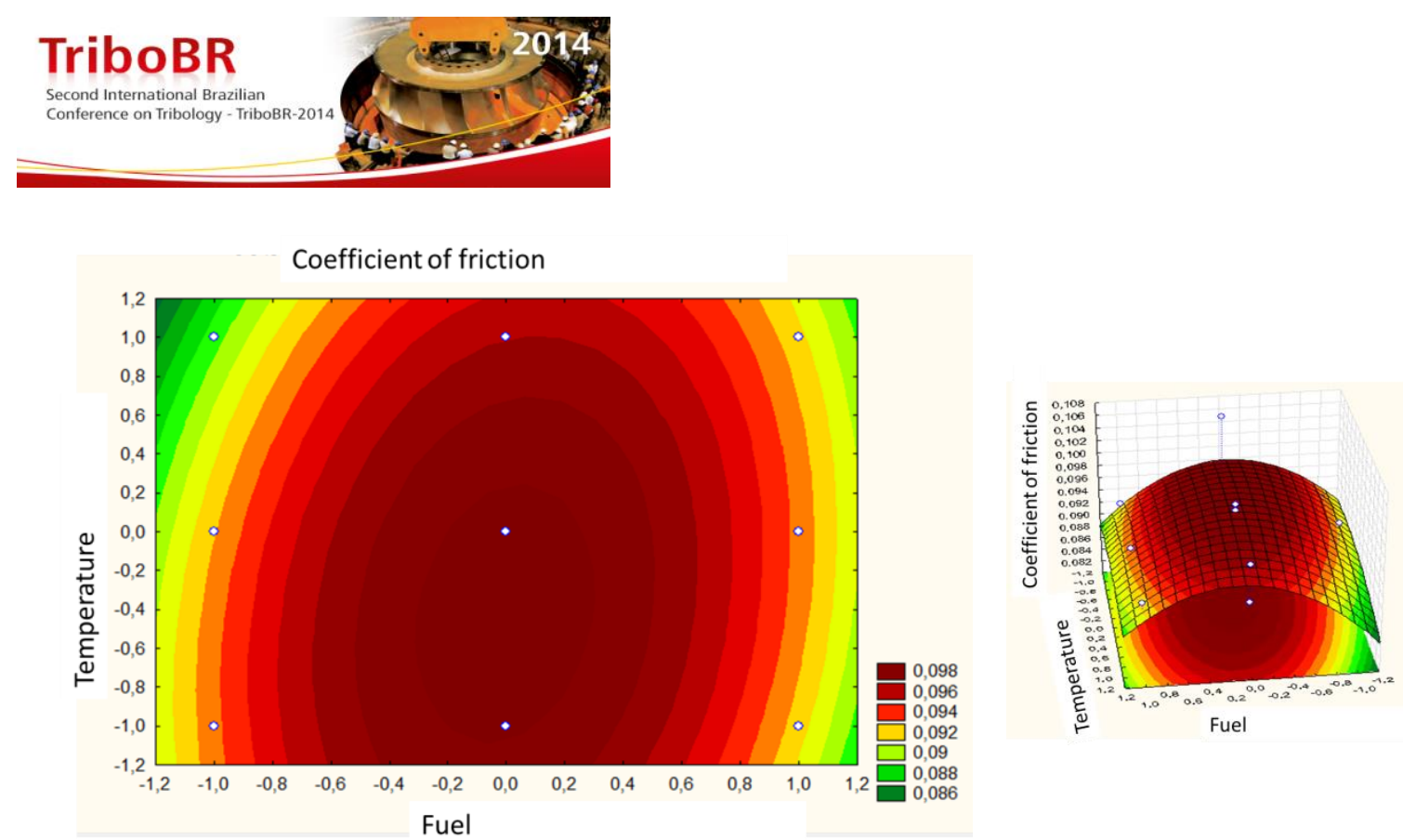

Figure 2. Response Surface and Contour generated for the coefficient of friction with respect to fuel and temperature.

According to Wadumesthrige et al. [9] the positive effect on lubricity at high temperatures is due to the increased molecular motion of polar components, which allows them to be better distributed on the metal's surface. As a conclusion, the chemical adsorption of polar compounds to the metal surface is greater at higher temperatures.

The response surface generated for WSD (Figure 3) confirms the influence of concentration and moisture of biodiesel in the lubricity (measured in terms of the wear scar diameter $(\mu \mathrm{m})$. Low WSD values were found for all fuels in the upper level of concentration, as observed to friction coefficient and higher WSD values to sunflower biofuel due the most moisture level.
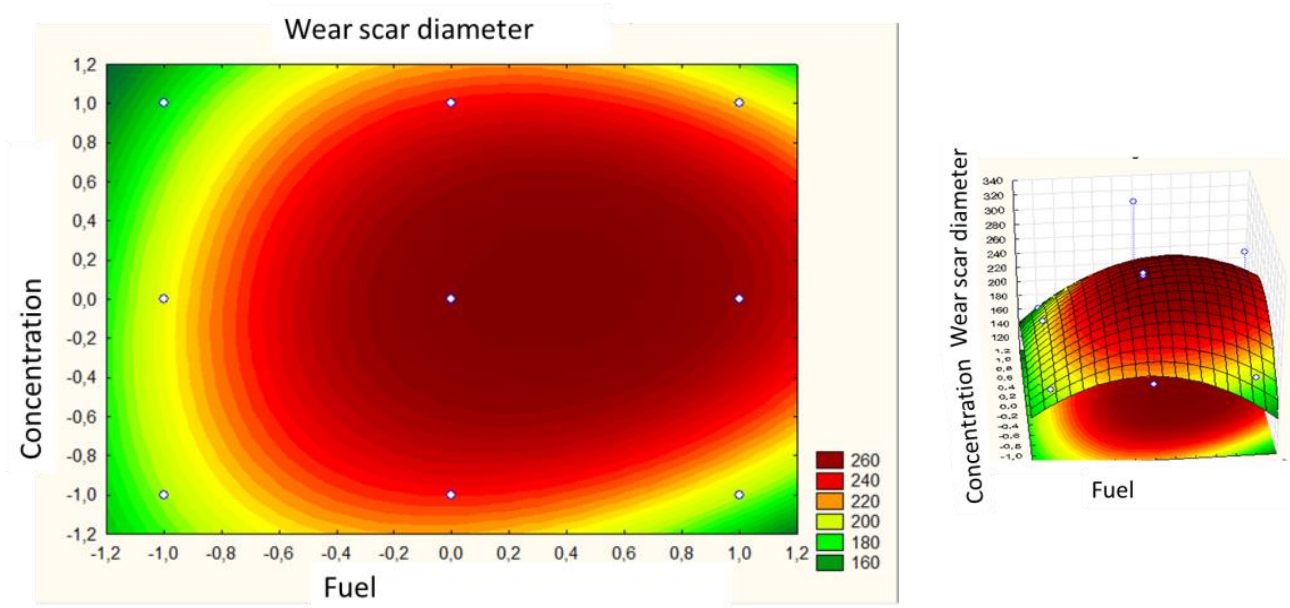

Figure 3. Response Surface and Contour generated for the Wear scar diameter with respect to fuel and concentration.

ANOVA (Table 5) generated by the statistical model applied on analysis showed regression coefficients relatively larger in compared to the friction coefficient, so that the applied model was better suited with respect to this variable response.

* Technical contribution to the $2^{\text {nd }}$ International Brazilian Conference on Tribology - TriboBR 2014, November $3^{\text {rd }}$ to $5^{\text {th }}$, 2014, Foz do Iguaçu, PR, Brazil. 


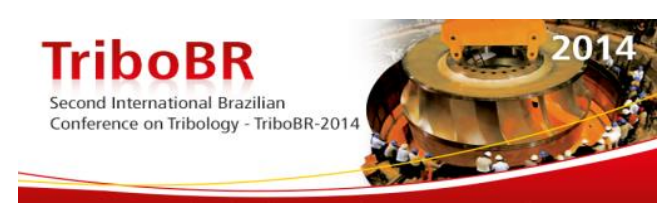

Table 5. ANOVA genered for the wear scar diameter

\begin{tabular}{|c|c|c|c|c|c|}
\hline \multirow[t]{2}{*}{ Factor } & \multicolumn{5}{|c|}{$\begin{array}{c}\text { ANOVA: WEAR SCAR DIAMETER } \\
\text { R-sqr:0.79198 }\end{array}$} \\
\hline & SS & $\begin{array}{l}\text { Degrees of } \\
\text { freedom }\end{array}$ & MS & $\mathrm{F}$ & $p$ \\
\hline (1)Fuel & 8121.88 & 2 & 4065.938 & 2.745729 & 0.177605 \\
\hline (2)Concentration & 5379.61 & 2 & 2689.803 & 1.816424 & 0.274629 \\
\hline (3)Temperature & 3519.34 & 2 & 1759.669 & 1.188305 & 0.393496 \\
\hline $1 * 2$ & 929.11 & 3 & 309.705 & 0.209144 & 0.885336 \\
\hline $1 * 3$ & 637.56 & 1 & 637.562 & 0.430546 & 0.547549 \\
\hline Error & 5923.29 & 4 & 1480.823 & & \\
\hline Total SS & 28474.33 & 14 & & & \\
\hline
\end{tabular}

The effect of fuel temperature observed in WSD confirms the results obtained by Wadumesthrige et al. [9], the lubrication ability of fuel was improved in high temperatures. Figure 4 shows that lubricity increases at the upper level fuel temperature.
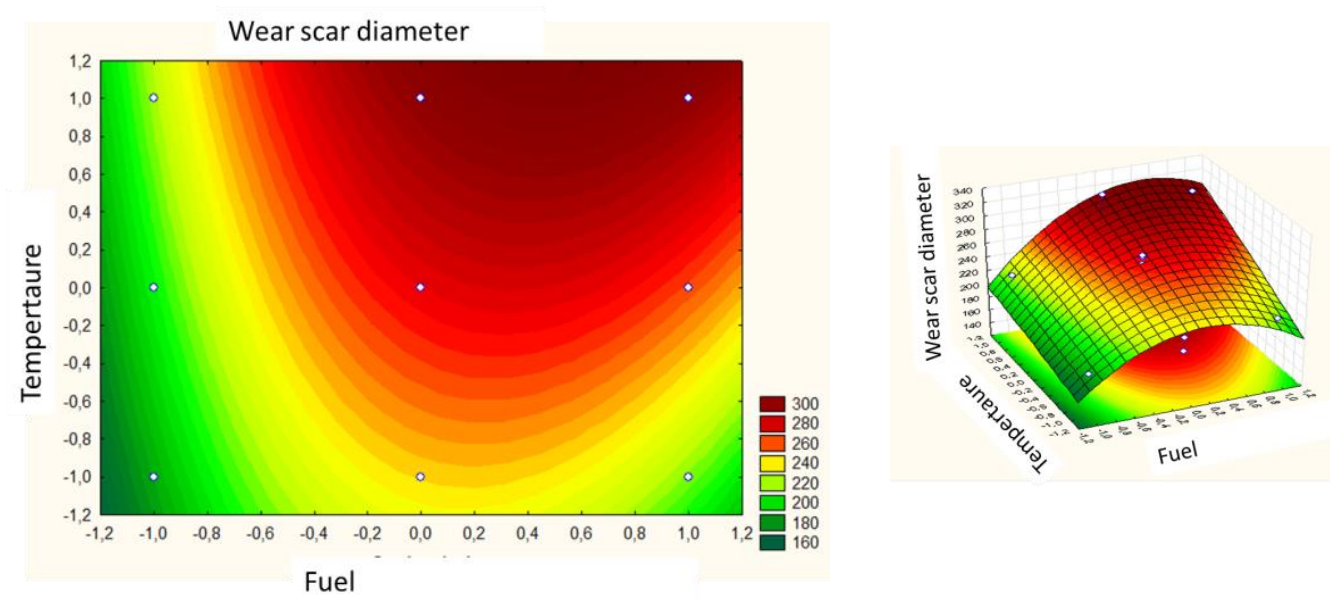

Figure 4. Response Surface and Contour generation for Diameter eschar wear on the ball compared to fuel and temperature

ANOVA (Table 6) generated for percentage of film formation using the statistical model mentioned above (Eq. 3) show relatively higher coefficients of regression than friction coefficient analysis (Tab. 4). So, the applied model was better suited in this variable.

Table 6. ANOVA generated for the percentage of film formed

\begin{tabular}{|c|c|c|c|c|c|}
\hline \multirow{2}{*}{ Factor } & \multicolumn{5}{|c|}{$\begin{array}{c}\text { ANOVA: PERCENTAGE OF FILM FORMED } \\
\text { R-sqr:0.68623 }\end{array}$} \\
\hline & SS & $\begin{array}{l}\text { Degrees of } \\
\text { freedom }\end{array}$ & MS & $F$ & $\mathrm{P}$ \\
\hline (1)Fuel & 45.9731 & 2 & 22.98654 & 0.608915 & 0.587679 \\
\hline (2)Concentration & 19.8109 & 2 & 9.90545 & 0.262396 & 0.781489 \\
\hline (3)Temperature & 79.3269 & 2 & 39.66346 & 1.050688 & 0.429798 \\
\hline $1 * 2$ & 8.5833 & 3 & 2.86111 & 0.075791 & 0.969822 \\
\hline $1 * 3$ & 2.2500 & 1 & 2.25000 & 0.059603 & 0.819136 \\
\hline Erro & 151.0000 & 4 & 37.75000 & & \\
\hline Total SS & 364.9333 & 14 & & & \\
\hline
\end{tabular}

* Technical contribution to the $2^{\text {nd }}$ International Brazilian Conference on Tribology - TriboBR 2014, November $3^{\text {rd }}$ to $5^{\text {th }}$, 2014, Foz do Iguaçu, PR, Brazil. 


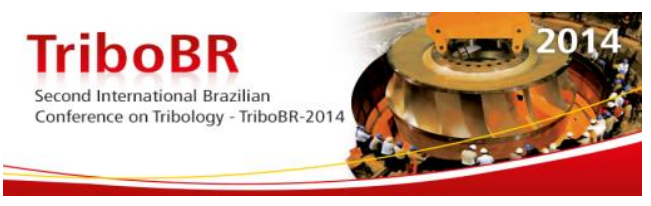

The response surface generated for percentage of film formation (Figure 05) for fuel and concentration showed that high percentage of film formation is reached for the concentration levels above of center and high point. These results are consistent with the literature $[4,5,6,8]$. The biodiesel lubricity is due to the presence of a polarityimparting heteroatom, the oxygen, as well the presence of a carbonyl moiety.
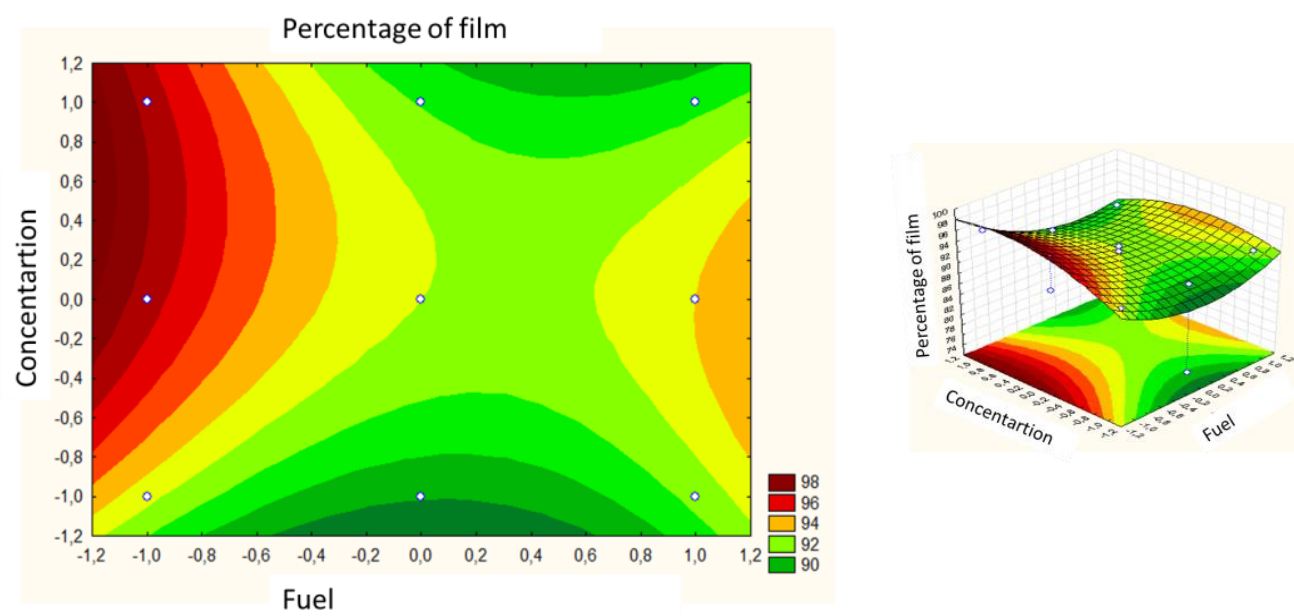

Figure 5. Response Surface and Contour generation for film formation in relation to fuel and concentration

The influence of fuel temperature on percentage of film formation is described by the contour surface graphic of Figure 6 . This figure presents a more uniform response surface, showing that the percentage of film has its optimum performance for analyzed temperature.

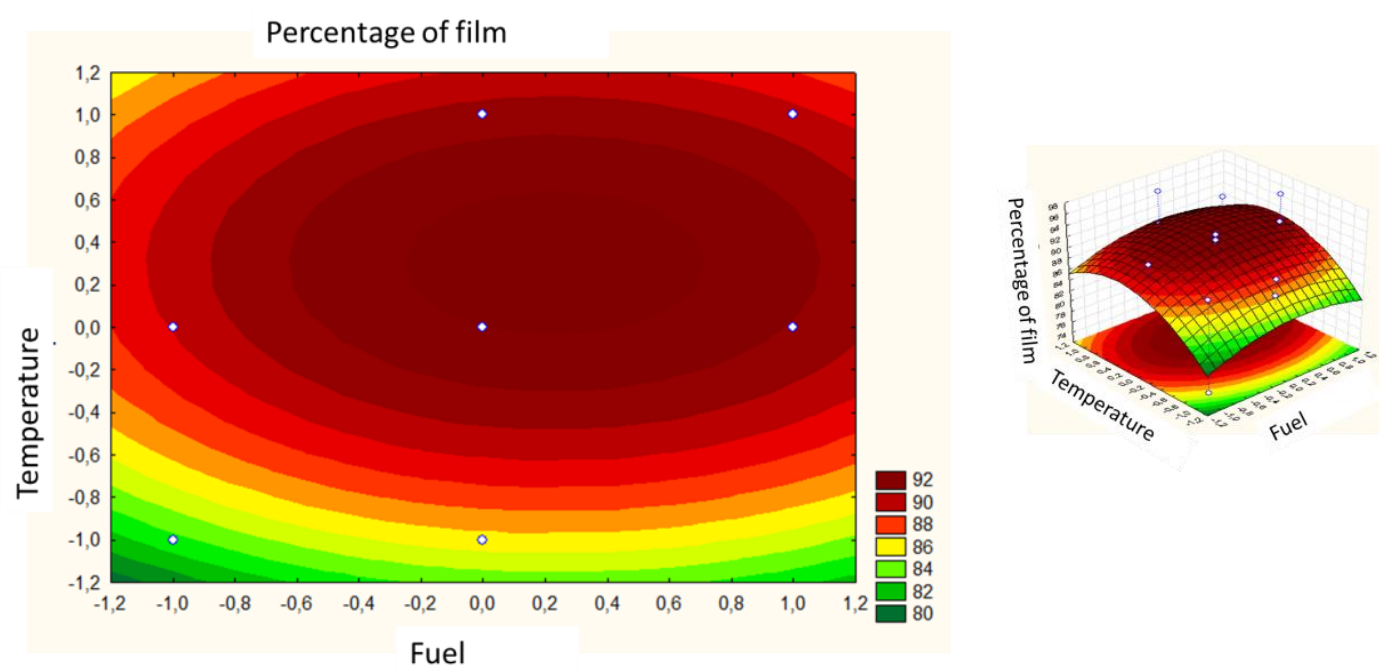

Figure 6. Response Surface and Contour generation for film formation compared to film formation in relation to temperature and concentration

For these variables there are not a significant influence of the concentration in the lubricity of the higher to intermediate point. However, there is a negative influence of the synergism by lowest levels of temperature and concentration. This synergism may compromise the lubrication system. It is a positive point because the working temperature of the engine are upper than studied in this work.

* Technical contribution to the $2^{\text {nd }}$ International Brazilian Conference on Tribology - TriboBR 2014, November $3^{\text {rd }}$ to $5^{\text {th }}$, 2014, Foz do Iguaçu, PR, Brazil. 


\section{CONCLUSION}

The analysis of the lubricity of biodiesels by response surface tool has shown that higher concentrations of biodiesel demonstrates greater effectiveness in protecting the metal in contact, with lower coefficients of friction and wear scar diameters. The lubricating action is positively influenced by fuel temperature $\left(40\right.$ and $\left.60^{\circ} \mathrm{C}\right)$ due to the increase of molecular motion of polar components, improving the molecules distribution on the metal's surface.

\section{Acknowledgments}

The authors would like thank the engineers and technicians of the following laboratories: Chemical Technology, NUPEG II, DEMat and Tribology for their assistance in the present work.

\section{REFERENCES}

1 Haas MJ, Scott KM, Alleman TL, Mccormick RL. Engine performance of Biodiesel fuel prepared from soybean soap stock: a high quality renewable fuel produced from a waste feedstock. Energy Fuels, 15: 1207-1212.

2 Diário Oficial da União (DOU). Medida Provisória n 647, de 28 de Maio de 2014.pg. 1. Seção 1.

3 Corrêa IMC, Maziero JVG, Ungaro MR, Bernardi JA, Storino. Desempenho de motor diesel com misturas de biodiesel de óleo de girassol.Ciênc. agrotec., Lavras, 2008; 32(3): 923-928.

4 Mello VS, Souza ERV, Oliveira MVA, Araújo Alves SM. Effect of desulfurization of diesel and its blends with biodiesel on metallic contact. Materials Research, 2014.

5 Sulek MW, Kulczycki A, Malysa A. Assessment of lubricity of compositions of fuel oil with biocomponents derived from rape-seed. Wear, 2010; 268, 2010, pp. 104-108

6 Nikanjam, M. and Henderson, P. Lubricity of Low Sulfur Diesel Fuels. SAE Technical Paper 932740, 1993, doi:10.4271/932740.

7 Camargos RRS. Avaliação da viabilidade de se produzir biodiesel através da transesterificação de óleo de grãos de café defeituosos. Dissertação (Mestrado)Escola de Engenharia da Universidade Federal de Minas Gerais, Belo Horizonte.2005.105p

8 Suarez PA.Z, Moser BR, Sharma BK, Erhan SZ. Comparing the lubricity of biofuels obtained from pyrolysis and alcoholysis of soybean oil and their blends with petroleum diesel. Fuel, 2009; 88: 1143-1147.

9 Wadumesthrige K, Ara M, Salley OS, Simon KY. Investigation of Lubricity Characteristics of Biodiesel in Petroleum and Synthetic Fuel. Energy e Fuels, 2009; 23: 2229-22344.

10 Gomes HO, Oliveira JF. Metodologia de Avaliação de Lubricidade do Óleo diesel. Boletim técnico da Petrobras, Rio de Janeiro, 2005.

11 Kwak JS. Application of Taguchi and response surface methodologies for geometric error in surface grinding process. Int J Machine Tools Manuf 2005; 45:327-334.

12 American Oil Chemists' Society. Official methods and recommended practices of the American Oil Chemists' Society. 4th ed. Champaign, USA, A.O.C.S., 1990.

13 ABNT NBR 14598:2007. Produtos de petróleo - Determinação do ponto de fulgor pelo aparelho de vaso fechado Pensky-Martens.2007.

14 Atabania AE, Silitonga AS, Badruddina IA, Mahliaa TMI, Masjukia HH, Mekhilef S. A comprehensive review on biodiesel as an alternative energy resource and its characteristics Renewable and Sustainable Energy Reviews 16, 2012, 2070- 2093.

* Technical contribution to the $2^{\text {nd }}$ International Brazilian Conference on Tribology - TriboBR 2014, November $3^{\text {rd }}$ to $5^{\text {th }}$, 2014, Foz do Iguaçu, PR, Brazil. 
15 Anastopoulos, G, Lois E, Zannikos F, Kalligeros S, Teas C. Influence of acetoacetic esters and di-carboxylic acid esters on diesel fuel lubricity. Tribology International 34, 2001, pp. 749-755.

16 Knothe G. Dependence of biodiesel fuel properties on the structure of fatty acid alkyl esters. Fuel Processing Technology 86 (2005)1059 - 1070.

17 Fazal MA; Hasseb ASMA, Masjuki HH. Biodiesel feasibility study: Na evaluation of material compatibility; performance; emission and engine durability. Renewable snd Sustainable Energy Reviews.15. 1314-1324.2011.

* Technical contribution to the $2^{\text {nd }}$ International Brazilian Conference on Tribology - TriboBR 2014, November $3^{\text {rd }}$ to $5^{\text {th }}, 2014$, Foz do Iguaçu, PR, Brazil. 